\title{
MODEL PEMBERDAYAAN MASYARAKAT DALAM PEMBEBASAN PASUNG MENURUT PERSPEKTIF BUDAYAJAWA
}

\author{
Imam Sunarno \\ Poltekkes Kemenkes Malang, Prodi Keperawatan Blitar, Jl. Dr. Soetomo, No.46 Blitar \\ Email : imam_sunarno@yahoo.com
}

\section{Community Empowerment Model In Liberation Airborne Java Cultural Perspective}

\begin{abstract}
The purpose of this study is developing model for community empowerment in airborne liberation Java Cultural perspective. To disassemble the model for community empowerment in airborne liberation cultural perspective Java. Must using two stages. The results of the research community empowerment with the most potential for development, knowledge in acquiring stocks are health cadres and for the people who behave for acquiring stocks are health workers (94\%), while society's most potential to organize and mobilize the environment to release stocks is a group of cadres health (100\%).
\end{abstract}

Keywords: empowerment, community non airborne

\begin{abstract}
Abstrak: Tujuan penelitian ini adalah mengembangkan model pemberdayaan masyarakat dalam pembebasan pasung menurut perspektif budaya Jawa. Penelitian ini menggunakan dua tahap. Hasil penelitian pemberdayaan masyarakat yang paling potensial untuk pengembangan, pengetahuan dalam pembebasan pasung adalah kader kesehatan dan bagi orang-orang yang berperilaku untuk pembebasan pasung adalah pekerja kesehatan (94\%), sementara masyarakat yang paling potensial untuk mengatur dan memobilisasi lingkungan untuk melepaskan pasung adalah kelompok kesehatan kader (100\%).
\end{abstract}

Kata kunci: Pemberdayaan, Komunitas non air borne

\section{PENDAHULUAN}

Gangguan kesehatan jiwa berat biasanya ditandai dengan tindakan perilaku kekerasan atau perilaku amuk yang dapat membahayakan dirinya maupun lingkungan. Kondisi ini membuat situasi keluarga dan masyarakat sekitarnya kurang kondusif sehingga biasanya keluarga dan masyarakat mengambil langkah-langkah yang berhubungan dengan perilaku distruktif, selanjutnya penderita dilakukan pemasungan. Hal ini dapat kita lihat kasus pemasungan di Pulau Jawa masih cukup tinggi sesuai dengan data Riskesdas Tahun 2013 jumlah prevalensi gangguan jiwa berat (psikosis / skizofrenia ) berjumlah $1,7 \%$, dari populasi atau sebanding dengan 400.000 penderita. Juga ditemukan $14,3 \%$ orang dengan gangguan jiwa (ODGJ) atau setara dengan 57.000 jiwa pernah mengalami pemasungan didalam kehidupannya.
Berdasarkan jumlah ODGJ yang dipasung kurang lebih 50.000 orang (Kemenkes RI, 2013).

Penderita ODGJ sebenarnya mempunyai hak yang sama dengan yang lain yaitu hak untuk mendapatkan perawatan dan pengobatan yang lebih manusiawi, tetapi kenyataannya justru dilakukan pemasungan. Larangan pemasungan menurut UU sesuai dengan amanat UU Kesehatan Jiwa No. 18 Tahun 2014 ODGJ berhak mendapatkan perawatan dan pengobatan yang layak dan manusiawi, dan melarang pemasungan pada penderita ODGJ walaupun kenyataannya sampai saat ini masih banyak yang dipasung. Ketentuan pelanggaran UU, jika terjadi pelanggaran Undang-Undang semuanya dapat dikenai sangsi pidana. Jumlah penderita pasung bukannya berkurang namun kenyataannya bertambah.

Pemerintah Daerah melalui Dinas Kesehatan dan Puskesmas serta instansi terkait juga sudah 
melakukan upaya pelepasan pemasungan, Pelepasan ini tidak dibarengi dengan program pemerintah lintas sektor dan kurang memperhatikan budaya masyarakat setempat sehingga program pembebasan pasung yang dicanangkan oleh Pemerintah ini terancam gagal.

Faktor lain yang dapat mempengaruhi kegagalan program pembebasan pasung adalah stigma yang ada di masyarakat. Menurut Goffman (1959) perilaku dikatakan menyimpang atau jahat akibat dari stigma untuk semua karakter dalam rangka mendiskreditkan seseorang. Stigma adalah penamaan yang sangat negatif kepada seseorang / kelompok sehingga mampu mengubah secara radikal konsep diri dan identitas sosial mereka. Adanya stigma akan membuat seseorang atau sebuah kelompok negatif dan diabaikan, sehingga mereka disisihkan secara sosial.

Untuk mengatasi permasalahan diatas diperlukan langkah-langkah kebijakan pembebasan pasung dengan meningkatkan peran serta masyarakat secara aktif yang disesuaikan dengan budaya masyarakat setempat agar program ini dapat diterima dan diterapkan untuk membebaskan pemasungan ODGJ di wilayah Jawa. Masyarakat yang dimaksud adalah mulai Pemerintah, keluarga, penderita, dan kelompok penjamu perlu diberdayakan untuk bersamasama mendukung pembebasan penderita yang dipasung. Peran budaya masyarakat disini sangat penting sebagai rasa tanggung jawab dan keterlibatan sebagai pemimpin (Ing Ngarso), sebagai pelaksana (Ing Madyo) dan sebagai pendukung (Tut Wuri) dalam membebaskan pasung yang dilakukan secara gotong royong oleh masyarakat.

Tujuan penelitian ini adalah untuk mengembangkan model pemberdayaan masyarakat dalam pembebasan pasung di wilayah Kota Blitar.

\section{METODE PENELITIAN}

Penelitian ini terdiri dari 2 tahap. Tahap I yaitu model pemberdayaan masyarakat dalam pembebasan pasung menurut perspektif budaya Jawa yang informasinya diperoleh dari hasil : 1) Survey pada keluarga, tokoh agama / tokoh masyarakat, kader kesehatan jiwa dan tenaga kesehatan (dokter/perawat) menurut Sunrise Theory yang terdiri a. Faktor Teknologi, b. Faktor Agama dan Flasafah Hidup, c. Faktor Sosial dan Keterikatan Keluarga, d. Faktor Nilai Budaya dan Gaya Hidup, e. Faktor Kebijakan dan Peraturan yang Berlaku, f. Faktor Ekonomi, g. Faktor Pendidikan, 2) Survey ini dilakukan dalam rangka analisis laporan kasus pemasungan ke Puskesmas atau Dinas Kesehatan. 3) Nominal Group Technique digunakan untuk mencari jalan keluar (Problem Solving) dari permasalahan penemuan ODGJ yang dipasung, sehingga diharapkan muncul model pengembangan penemuan kasus pemasungan baru.

Tahap II terdiri dari implementasi dan evaluasi efektifitas model penemuan dan pembebasan pasung yang terbentuk. Menguji efektifitas dan penilaian model sistem penemuan dan cara pembebasan pasung dengan pemberdayaan masyarakat baik tingkat Keluarga, Tokoh Agama (TOGA)/ Tokoh Masyarakat (TOMA), Kader Keswa, tenaga kesehatan yang dihasilkan dari tahap I menggunakan rancangan percobaan lapangan post test only control group design dengan memakai 2 kelompok perlakuan dan kontrol.

Penelitian inimenggunakan kuasi eksperimen atau cross sectional pada masyarakat wilayah Kota Blitar. Populasi yang digunakan adalah seluruh masyarakat (Keluarga, TOGA/TOMA, Kader Keswa, Tenaga Kesehatan) yang ada diwilayah kota Blitar yang aktif berpartisipasi dalam kegiatan penanganan gangguan jiwa yang dipasung dan pembebasan pasung dengan jumlah 


\section{0 sampel}

Pengumpulan data yang dilakukan dengan menggunakan observasi dan kuesioner. Data yang diperoleh dari instrument pengumpulan data dikumpulkan dalam lembar pengumpul data, kemudian dikoding sesuai lembar kode data yang sudah dibuat. Kemudian data dimasukkan (di entry) ke dalam komputer. Data kuantitatif yang sudah diolah disajikan secara tabular dan tekstuler. Data analisis data secara deskriptif dengan penilaian terhadap unsur : 1) Pengembangan kemampuan masyarakat untuk melepaskan penderita yang dipasung, 2) Mengubah perilaku masyarakat untuk membebaskan penderita dari pemasungan, 3) Mengorganisir diri masyarakat untuk bersatu padu membebaskan penderita dari pemasungan.

Data Primer yang dikumpulkan berdasarkan kasus ODGJ yang dilakukan pemasungan dan pembebasan pasung yang dilaporkan oleh masyarakat (keluarga, TOGA / TOMA, Kader Keswa, Tenaga Kesehatan) ke Puskesmas atau Dinas Kesehatan Kota Blitar sebagai kelompok intervensi maupun kelompok kontrol. Data Sekunder yang dikumpulkan berdasarkan kependudukan dan indikator kasus ODGJ yang dipasung di wilayah Puskesmas Kota Blitar Tahun 2015, yang digunakan untuk menjamin homogenitas kelompok intervensi dan kontrol.

Data penelitian disajikan dalam bentuk tabel, kemudian dilakukan analisis uji efektifitas model dengan membandingkan luaran/output kelompok intervensi dan kontrol. Data perubahan perilaku sebelum dan sesudah intervensi dianalisis dengan menggunakan uji Structural Equation Modeling (SEM) untuk membuktikan ada tidaknya perubahan setelah intervensi. Kelompok intervensi dan kontrol dibandingkan luaran berupa jumlah dan proposi suspek penemuan dan pembebasan pasung.

Tempat dan waktu penelitian di wilayah kerja Dinkes Kota Blitar mulai bulan Mei 2016 sampai dengan September 2016.

\section{HASIL PENELITIAN}

Diskripsi daerah Blitar ini diberikan secara relatif singkat dan menyangkut hal-hal yang berkaitan langsung dengan perspektif budaya Jawa dan kesehatan masyarakat Blitar. Blitar dibagi dalam wilayah Kota dan wilayah Kabupaten yang masing-masing memiliki pusat pemerintahan sendiri. Tujuannya adalah agar uraian hasil analisis terhadap data pada bab selanjutnya dapat lebih dipahami. Gambaran umum wilayah Kota Blitar merupakan sebuah data dasar yang digunakan sebagai acuan dalam penyusunan perencanaan pembangunan kesehatan yang evidence based, sehingga perencanaan program maupun kegiatan bidang kesehatan sesuai dengan kebutuhan masyarakat dan kondisi faktual di wilayah Kota Blitar.

Blitar merupakan daerah bumi Bung Karno sebab tempat Proklamator tumbuh dan berkembang sejak kecil sampai dewasa terbukti dari prasasti batu bertulis di makam Proklamator desa Bendogerit dan Istana Gebang. Blitar disebut juga Kota Lahar sebab secara periodik terkena lahar dari gunung berapi yaitu Gunung Kelud yang berada di sebelah utara Kabupaten Blitar berbatasan dengan Kabupaten Kediri. Blitar terdapat situs peninggalan tempat pemujaan dari Kerajaan Mojopahit yaitu Candi Penataran. Blitar tempat pemakaman Raden Wijaya sebagai raja Mojopahit pertama, yang terdapat situs peninggalan Candi Simping di wilayah Kademangan. Blitar merupakan tempat perjuangan tokoh spiritual agama Islam yaitu Syeh Subakir, dimakamkan di wilayah Penataran pernah berjasa menanam tumbal di tanah Jawa. Blitar merupakan tempat perjuangan tokoh pejuang dari keraton Mataram untuk melawan penjajah Belanda, dengan situs peninggalan tempat peristirahatan Eyang Jugo yang terdapat di Kesamben. Blitar tempat perjuangan pembebasan bangsa dan negara dari penjajahan 
Jepang dengan peninggalan tentara PETA Supriyadi. Blitar memiliki Pusaka Daerah yang bernama Gong Kyai Pradah yang disimpan di wilayah Lodoyo.

Kota Blitar merupakan wilayah terkecil kedua di Propinsi Jawa Timur setelah Kota Mojokerto. Terletak pada koordinat $112^{\circ} 114^{\prime}-$ $12^{\circ} 28^{\prime}$ Bujur Timur dan $8^{\circ} 2^{\prime}-8^{\circ} 10^{\prime}$ Lintang Selatan atau tepatnya terletak sekitar $160 \mathrm{~km}$ sebelah selatan Kota Surabaya, ibukota Propinsi Jawa Timur. Suhu udara rata-rata berkisar pada $29^{\circ} \mathrm{C}$ dengan type iklim C-3. Kondisi seperti menjadikan Kota Blitar sebagai sebuah daerah yang nyaman untuk dijadikan tempat hunian dan peristirahatan. Luas wilayah Kota Blitar adalah $\pm 32,578 \mathrm{~km}^{2}$, terdiri atas 3 (tiga) kecamatan, 21 Kelurahan.

Jumlah penduduk Kota Blitar tahun 2010 sebanyak 139. 971 jiwa dengan komposisi penduduk laki-laki dan perempuan tidak berbeda jauh jumlahnya, penduduk laki-laki masih lebih kecil sejumlah 69. 855 jiwa sedangkan penduduk perempuan sejumlah 70 . 116 jiwa. Distribusi penduduk terbesar adalah pada kelompok umur 15-19 tahun 16. 286 jiwa.

Salah satu indikator keberhasilan pembangunan adalah kualitas kesehatan masyarakat

Tabel 1. Distribusi Umur Responden

\begin{tabular}{lcc}
\hline Umur & n & \% \\
\hline$<25$ Tahun & 7 & 5 \\
26 - 45 Tahun & 70 & 46 \\
46 - 60 Tahun & 59 & 39 \\
$>$ 61 Tahun & 14 & 10 \\
\hline Total & 150 & 100 \\
\hline
\end{tabular}

Tabel 2. Distribusi Responden berdasarkan Pendidikan

\begin{tabular}{lcc}
\hline Pendidikan & n & \% \\
\hline Dasar & 42 & 28 \\
Menengah & 65 & 43 \\
Tinggi & 43 & 29 \\
\hline Total & 150 & 100 \\
\hline
\end{tabular}

yang diukur dengan umur harapan hidupnya, oleh karena itu segala upaya dilakukan agar seluruh lapisan masyarakat mendapatkan pelayanan kesehatan secara mudah dan merata. Upaya yang dilakukan pemerintah antara lain dengan membangun dan melengkapi sarana dan prasarana kesehatan serta meningkatkan mutu pelayanan dibidang kesehatan, selain itu pemerintah juga mengupayakan pelayanan kesehatan gratis bagi mereka yang tidak mampu melalui program Jamkesmas dan Jamkesda. Umur harapan hidup untuk kota Blitar pada tahun 2010 adalah 72, 7 tahun (data BPS kota).

Puskesmas sampai dengan tahun 2010, jumlah Puskesmas yang ada di Kota Blitar sebesar 3 unit dengan 2 Puskesmas Perawatan. Hal ini berarti untuk Kota Blitar rata-rata 1 Puskesmas

Tabel 3. Pengembangan Kemampuan Masyarakat untuk Melepaskan Penderita Pasung

\begin{tabular}{lccc}
\hline \multirow{2}{*}{ Kemampuan } & \multicolumn{2}{c}{ Jumlah } & \multirow{2}{*}{$\%$} \\
\cline { 2 - 3 } & \multicolumn{3}{c}{} \\
\hline Tinggi & 134 & 136 & 90 \\
Cukup & 14 & 7 & 7 \\
Rendah & 2 & 7 & 3 \\
\hline Total & 150 & 150 & 100 \\
\hline
\end{tabular}

Tabel 4. Mengubah Perilaku Masyarakat untuk Membebaskan Penderita dari Pemasungan

\begin{tabular}{lcccc}
\hline \multirow{2}{*}{ Perilaku } & \multicolumn{3}{c}{ Jumlah } & $\%$ \\
\cline { 2 - 4 } Tinggi & 132 & 116 & 118 & 81 \\
Cukup & 13 & 21 & 19 & 12 \\
Rendah & 5 & 13 & 13 & 7 \\
\hline Total & 150 & 150 & 150 & 100 \\
\hline
\end{tabular}

Tabel 5. Kemampuan Mengorganisir Diri dan Masyarakat untuk Membebaskan Penderita dari Pemasungan

\begin{tabular}{lcc}
\hline Mengorganisir & n & \% \\
\hline Tinggi & 140 & 94 \\
Cukup & 7 & 4 \\
Rendah & 3 & 2 \\
\hline Total & 150 & 100 \\
\hline
\end{tabular}


di Kecamatan harus bisa melayani 44. 513 jiwa. Rumah Sakit. Di Kota Blitar ada 1 rumah sakit pemerintah yang mampu memberikan pelayanan memadai karena telah dilengkapi dengan tenaga dana sarana prasarana yang cukup lengkap. Selain rumah sakit pemerintah, di kota Blitar terdapat 3 rumah sakit swasta yang siap melayani masyarakat Kota Blitar dan sekitarnya. Rumah Sakit Pemerintah di Kota Blitar sudah terakreditasi Paripurna.

\section{PEMBAHASAN}

Berdasarkan gambar 1 terdapat variabel yang tidak signifikan dengan nilai pengaruh sebesar 0,00 , selanjutnya dilakukan analisis lanjutan dengan menghilangkan variabel yang memiliki pengaruh 0,00 sebanyak tiga kali. Hasil analisis terakhir yaitu keempat dihasilkan nilai pengaruh setiap variabel lebih besar dari 0,00 . Hal ini dapat diketahu pada Gambar 2. Nilai hasil analisis keempat seperti tabel 6.

Sesuai hasil akhir analisis besar pengaruh seluruh variabel terhadap variabel Y3 (mengorganisir masyarakat untuk membebaskan penderita dari pemasungan) sebesar 0,174 berarti seluruh variabel berpengaruh sebesar $17,4 \%$ sedangkan sebesar $82,6 \%$ dipengaruhi faktor lain yang tidak diteliti.

Baik umur, jenis kelamin, tingkat pendidikan, bekerja, lama bekerja dari masyarakat berpengaruh pada Y2 (mengubah perilaku untuk membebaskan penderita dari pemasungan) sebesar 0,04

F1 - Faktor Tehnologi. Kemajuan tehnologi dalam budaya berpengaruh pada Y2 (mengubah perilaku untuk membebaskan penderita dari pemasungan) sebesar $-0,03$

F2 - Faktor Agama dan Filsafat Hidup . Kemajuan Agama dan Filsafat Hidup dalam budaya berpengaruh pada Y1 (mengembangkan kemampuan masyarakat untuk melepaskan penderita pasung) sebesar 0,03 .

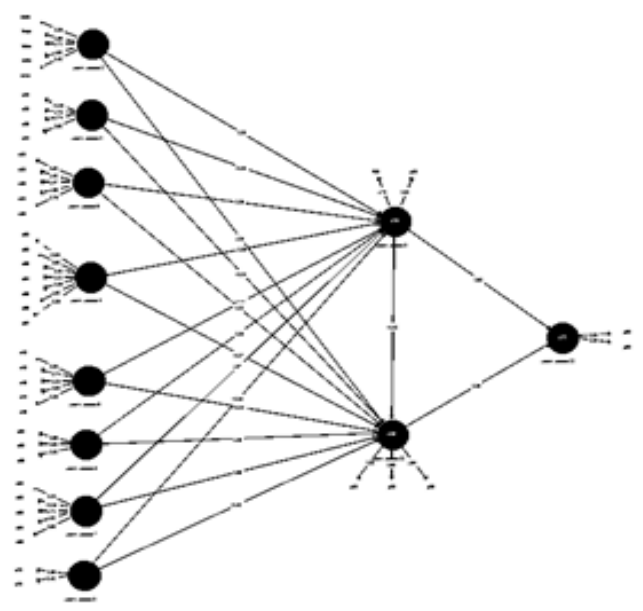

\section{Gambar 1. Nilai Pengaruh Setiap Variabel Berdasarkan Hasil Analisis Menggunakan PLS Student versi 3.6.023}

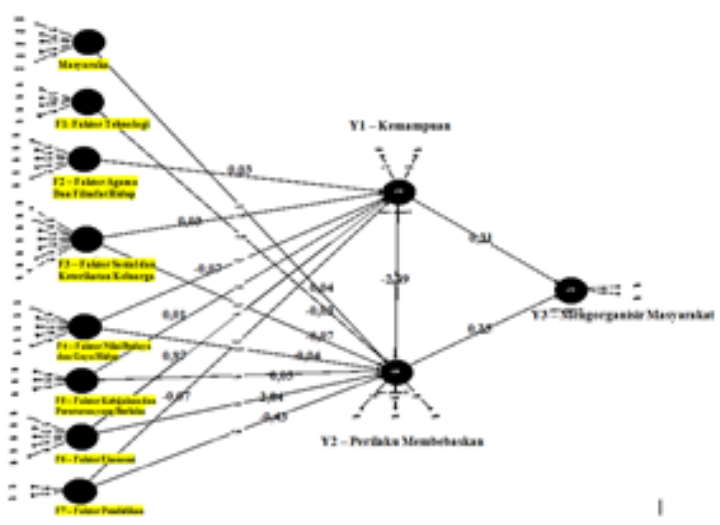

Gambar 2. Nilai Akhir Pengaruh (Analisis Keempat) setiap Variabel Berdasarkan Hasil Analisis Menggunakan PLS Student versi 3.6.023

F3 - Faktor Sosial dan Keterikatan Keluarga. Kemajuan Sosial dan Keterikatan Keluarga dalam budaya berpengaruh pada Y1 (mengembangkan kemampuan masyarakat untuk melepaskan penderita pasung) sebesar 0,03 dan pada Y2 (mengubah perilaku untuk membebaskan penderita dari pemasungan) sebesar -0,07

F4 - Faktor Nilai Budaya dan Gaya Hidup. Kemajuan Nilai Budaya dan Gaya Hidup dalam budaya berpengaruh pada Y1 (mengembangkan 
Tabel 6. Tabel Nilai Akhir Pengaruh (Analisis Keempat) Setiap Variabel Penelitian

\begin{tabular}{lccc}
\hline \multirow{2}{*}{\multicolumn{1}{c}{ Variabel bebas }} & \multicolumn{3}{c}{ Variabel Tergantung } \\
\cline { 2 - 4 } & Kemampuan & Perilaku & Organisir \\
\cline { 2 - 4 } & & 0,04 & \\
\hline Masyarakat & & $-0,03$ & \\
F1 - Faktor Tehnologi & 0,03 & & \\
F2 - Faktor Agama dan Filsafat Hidup & 0,03 & $-0,07$ & \\
F3 - Faktor Sosial dan Keterikatan Keluarga & $-0,07$ & $-0,04$ & \\
F4 - Faktor Nilai Budaya dan Gaya Hidup & 0,01 & 0,05 & \\
F5 - Faktor Kebijakan dan Peraturan yang & 0,97 & 2,84 & \\
berlaku & $-0,07$ & $-0,43$ & \\
F6 - Faktor Ekonomi & & $-2,39$ & 0,31 \\
F7 - Faktor Pendidikan & & & \\
Y1 - Pengembangan Kemampuan Masyarakat & & & 0,25 \\
untuk melepaskan penderita pasung & & & \\
Y2 - Mengubah perilaku masyarakat untuk & & & \\
membebaskan penderita dari pemasungan & & & \\
\hline
\end{tabular}

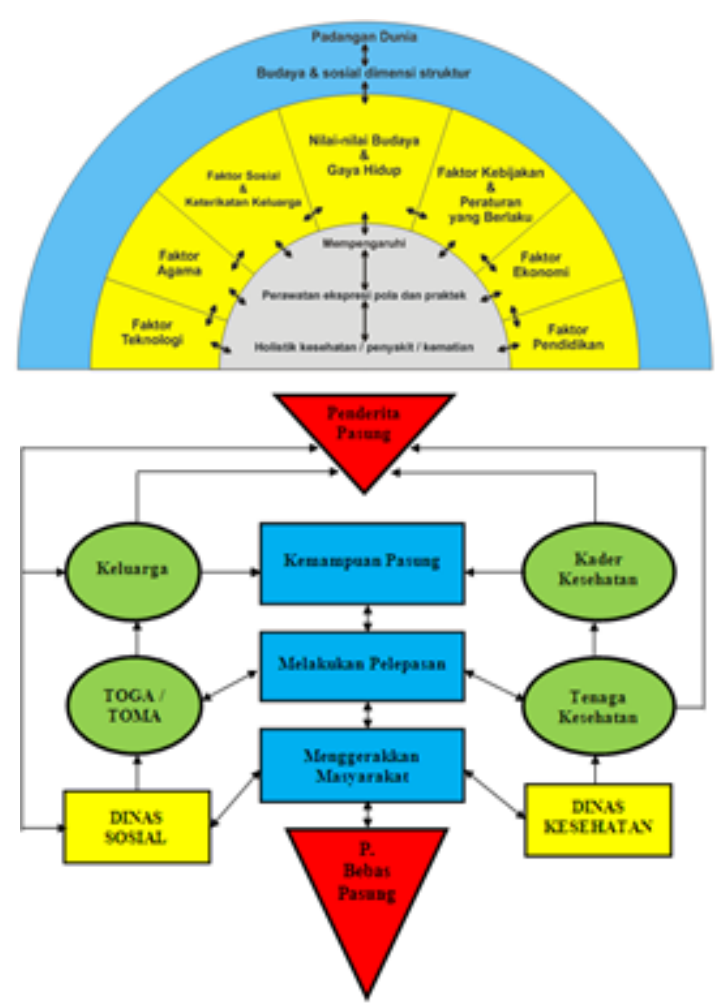

Gambar 3. Pengembangan Model Pemberdayaan Masyarakat Dalam Pembebasan Pasung Menurut Perspektif Budaya 
Tabel 7. Hasil Evaluasi Model Pemberdayaan Masyarakat Dalam Pembebasan Pasung Menurut Perspektif Budaya Jawa

\begin{tabular}{lcccc}
\hline \multicolumn{1}{c}{ Uraian } & Keluarga & $\begin{array}{c}\text { TOGA/ } \\
\text { TOMA }\end{array}$ & $\begin{array}{c}\text { Kader } \\
\text { Kesehatan }\end{array}$ & $\begin{array}{c}\text { Petugas } \\
\text { Kesehatan }\end{array}$ \\
\hline $\begin{array}{l}\text { Pengembangan kemampuan masyarakat } \\
\text { untuk melepaskan pasung }\end{array}$ & cukup & sedang & tinggi & tinggi \\
$\begin{array}{l}\text { Melakukan pembebasan penderita yang } \\
\text { dipasung }\end{array}$ & tinggi & sedang & sedang & tinggi \\
$\begin{array}{l}\text { Menggerakkan masyarakat untuk } \\
\text { membebaskan penderita dari pemasungan }\end{array}$ & cukup & tinggi & tinggi & sedang \\
\hline
\end{tabular}

kemampuan masyarakat untuk melepaskan penderita pasung) sebesar -0,07 dan pada Y2 (mengubah perilaku untuk membebaskan penderita dari pemasungan) sebesar -0,04

F5 - Faktor Kebijakan dan Peraturan yang berlaku. Kemajuan Kebijakan dan Peraturan yang berlaku dalam budaya berpengaruh pada Y1 (mengembangkan kemampuan masyarakat untuk melepaskan penderita pasung) sebesar 0,01 dan pada Y2 (mengubah perilaku untuk membebaskan penderita dari pemasungan) sebesar 0,05

F6 - Faktor Ekonomi. Kemajuan Ekonomi dalam budaya berpengaruh pada Y1 (mengembangkan kemampuan masyarakat untuk melepaskan penderita pasung) sebesar 0,97 dan pada Y2 (mengubah perilaku untuk membebaskan penderita dari pemasungan) sebesar 2,84

F7 - Faktor Pendidikan. Kemajuan Pendidikan dalam budaya berpengaruh pada Y1 (mengembangkan kemampuan masyarakat untuk melepaskan penderita pasung) sebesar -0,07 dan pada Y2 (mengubah perilaku untuk membebaskan penderita dari pemasungan) sebesar -0,43

Y1 - Pengembangan Kemampuan Masyarakat untuk melepaskan penderita pasung dalam Budaya berpengaruh pada Y2 (mengubah perilaku untuk membebaskan penderita dari pemasungan) sebesar -2,39 dan pada Y3 (mengorganisir masyarakat untuk membebaskan penderita dari pemasungan) sebesar 0,31

Y2 - Mengubah perilaku masyarakat untuk membebaskan penderita dari pemasungan dalam Budaya berpengaruh pada Y3 (mengorganisir masyarakat untuk membebaskan penderita dari pemasungan) sebesar 0,25

\section{Tahap I - Implementasi}

Setelah model pemberdayaan masyarakat dalam pembebasan pasung menurut perspektif budaya jawa diimplementasikan pada keluarga yang memiliki anggota yang sedang dipasung yang berada di UPTD Kepanjenkidul, UPTD Sananwetan dan UPTD Sukorejo didapatkan dari keluarga siap jika anggota keluarganya dirujuk ke Rumah Sakit Jiwa dengan harapan untuk pembiayaan secara gratis. Keluarga merasa lebih senang dengan adanya kunjungan oleh petugas dan penanganan petugas kesehatan untuk melakukan perawatan dan pengobatan pada ODGJ yang selama ini keluarga merasa sangat disibukkan dalam merawat penderita sehingga dilakukan pemasungan dan untuk selanjutnya siap untuk dibebaskan jika ada bantuan petugas.

Dari unsur Kader Kesehatan Jiwa berharap ada petunjuk tehnis langkah-langkah yang harus dilakukan untuk membantu keluarga didalam membebaskan pemasungan pada ODGJ untuk mendapatkan perawatan yang lebih layak. Kader merasa siap membantu jika diperlukan bersama dengan tenaga kesehatan dengan seijin keluarga untuk mengambil langkah-langkah pembebasan pemasungan. Dari TOGA/TOMA bersedia 
untuk mengkoordinir masyarakat dan memberikan wawasan kepada keluarga maupun lingkungan agar kasus pemasungan yang ada di wilayahnya segera dibebaskan dan mendapat perawatan yang semestinya. Dari Petugas Kesehatan, petugas siap melaksanakan pembebasan pasung jika semua persyaratan kelengkapan administrasi yang berasal dari keluarga penderita maupun kesiapan rombongan beserta alat transportasi/ ambulan sudah berhasil dikoordinasikan dan tidak berbenturan dengan kegiatan yang lain.

\section{Tahap II - Evaluasi}

Model pemberdayaan masyarakat dalam pembebasan pasung dapat dinilai berdasarkan evaluasi sistim kemampuan melepas pasung, melakukan pembebasan pasung, penggerakan masyarakat dalam pembebasan pasung.

Tabel 7 menunjukkan bahwa tidak terdapat kesulitan dalam mengaplikasikan model yang efektif dalam pembebasan pasung.

Faktor transkultural dalam masyarakat (Keluarga, TOGA/TOMA, Kader Kesehatan, Tenaga Kesehatan) terhadap karakteristik masyarakat. Faktor tehnologi yang tinggi dalam budaya terhadap kelompok Keluarga sebesar $85 \%$, pada TOGA/TOMA sebesar $81 \%$, pada Kader Kesehatan sebesar 91\%, pada Tenaga Kesehatan sebesar $96 \%$ dan total rata-rata jumlah faktor tehnologi yang tinggi sebesar $88 \%$, sedangkan rata-rata jumlah faktor tehnologi yang cukup hanya $6 \%$ dan yang rendah hanya $6 \%$.

Menurut Koentjaraningrat (1994) unsurunsur kebudayaan yang ada di dunia ini adalah; sistem religi dan upacara keagamaan, sistem dan organisasi kemasyarakatan, sistem pengetahuan, bahasa, kesenian, sistem mata pencaharian hidup, dan sistem teknologi dan peralatan.

Dari ketujuh unsur tersebut yang akan menjadi telaahan adalah sistem pengetahuan khususnya ilmu pengetahuan dan sistem teknologi. Ilmu dan teknologi sebagai kerangka kebudayaan dapat dilihat, pertama sebagai kekuatan produksi, kedua sebagai ideologi yang didalam termasuk politik, ketiga sebagai kerangka kebudayaan modern, dan keempat mencari relevansi bagi pembangunan Indonesia (Wartaya, 1987).

Hal ini sesuai dengan pendapat peneliti bahwa tehnologi yang tinggi dalam budaya masyarakat mempengaruhikarakteristik seluruh anggota masyarakatnya karena perkembangan ilmu pengetahuan dan tehnologi yang ada di masyarakat tumbuh dan berkembang berdasarkan kemajuan yang diterapkan oleh masyarakat, diadopsi oleh masyarakat dijaga dan dilakukan oleh masyarakat.

Faktor agama dan falsafah hidup terhadap karakteristik masyarakat sesuai fakta diatas, bahwa faktor agama dan falsafah hidup yang tinggi dari unsur Keluarga sebesar 57\%, pada TOGA/TOMA sebesar $74 \%$, pada Kader Kesehatan sebesar $73 \%$, pada Tenaga Kesehatan sebesar 70\%, rata-rata jumlah pengaruh budaya dari faktor agama dan falsafah hidup sebesar $68 \%$ sedangkan yang cukup sebesar $15 \%$ dan yang rendah $17 \%$.

Hal ini sesuai dengan teori Suwarno Imam S. dalam bukunya Konsep Tuhan, Manusia, Mistik dalam berbagai kebatinan Jawa halaman 57 kebudayaan spiritual Jawa menyatakan kepercayaan spiritual dalam kehidupan manusia di Dunia sudah diatur oleh alam semesta sehingga tidak sedikit manusiabersikap nrimo (menerima) dan menyerahkan diri kepada takdir.

Hal ini sejalan dengan pendapat Niels Mulder (1980), bahwa orang Jawa berpandangan segala sesuatu itu pada hakikatnya adalah satu, yaitu satu kesatuan hidup. Oleh karenanya kehidupan manusia selalu terpaut dalam kesatuan kosmos alam raya yang bersifat religius. Faktor agama dan falsafah hidup dalam budaya masyarakat terhadap karakteristik 
masyarakat kurang signifikan karena hanya $68 \%$.

Hal ini disebabkan karena masyarakat beranggapan bahwa faktor agama dan falsafah hidup ini merupakan kebutuhan universal sehingga karakter masyarakat antara kelompok Keluarga TOGA/TOMA, Kader Kesehatan, Tenaga Kesehatan sama-sama memiliki hubungan vertikal yang baik antara kelompok satu dengan yang lain sesuai dengan keyakinannya masingmasing.

Faktor sosial dan keterikatan keluarga terhadap karakteristik masyarakat sesuai fakta diatas, bahwa faktor sosial dan keterikatan keluarga yang tinggi dari unsur Keluarga sebesar $80 \%$, pada TOGA/TOMA sebesar $75 \%$, pada Kader Kesehatan sebesar $72 \%$, pada Tenaga Kesehatan sebesar $79 \%$, rata-rata jumlah pengaruh budaya dari faktor sosial dan keterikatan keluarga sebesar $76 \%$ sedangkan yang cukup sebesar 9\% dan yang rendah $15 \%$.

Faktor sosial dan keterikatan keluarga dalam budaya masyarakat terhadap karakteristik masyarakat yang signifikan sebesar $76 \%$. Menurut Koentjaraningrat menyatakan, dalam tingkah lakunya manusia yang hidup dalam suatu kebudayaan akan berpedoman kepada tokohtokoh pemimpin, orang senior, atau atasan. Kebudayaan lain lebih mementingkan hubungan horizontal antara manusia dengan sesamanya, sehingga mereka akan sangat merasa tergantung kepada sesamanya (berjiwa gotong royong).

Faktor nilai-nilai budaya dan gaya hidup terhadap karakteristik masyarakat sesuai fakta diatas, bahwa faktor nilai-nilai budaya dan gaya hidup yang tinggi dari unsur Keluarga sebesar $75 \%$, pada TOGA/TOMA sebesar 74\%, pada Kader Kesehatan sebesar $76 \%$, pada Tenaga Kesehatan sebesar $85 \%$, rata-rata jumlah pengaruh budaya dari faktor nilai-nilai budaya dan gaya hidup sebesar $78 \%$ sedangkan yang cukup sebesar $13 \%$ dan yang rendah $9 \%$.

Faktor nilai-nilai budaya dan gaya hidup dalam budaya masyarakat terhadap karakteristik masyarakat yang signifikan sebesar $78 \%$. Menurut Kluckhohn mengenai lima masalah dasar dalam hakekat hidup terkait dengan nilai budaya dan gaya hidup manusia menyatakan hidup itu buruk tetapi manusia wajib berikhtiar supaya hidup itu menjadi baik (Hills, 2002). Sejalan dengan fakta dan teori diatas bahwa budaya masyarakat Blitar didalam mengatasi masalah dasar didalam kehidupan (hakekat hidup) bahwa kondisi penderita yang sedang dipasung adalah kondisi kehidupan yang buruk. Sehingga masyarakat berkeyakinan dengan berupaya melakukan melepaskan penderitaan ODGJ yang dipasung dan diberikan pelayanan perawatan dan pengobatan yang lebih manusiawi menjadi kondisinya lebih baik sehingga penderita mampu memenuhi kebutuhan dasarnya baik didalam bersosial menggunakan bahasa yang digunakan dengan orang lain, memenuhi kebutuhan makan dan minumnya, serta melakukan aktivitas sehari-hari sebagai orang yang sehat dan mendapat perlakukan yang lebih wajar.

Faktor kebijakan dan peraturan yang berlaku terhadap karakteristik masyarakat sesuai fakta diatas, bahwa faktor kebijakan dan peraturan yang berlaku yang tinggi dari unsur Keluarga sebesar $86 \%$, pada TOGA/TOMA sebesar 91\%, pada Kader Kesehatan sebesar 89\%, pada Tenaga Kesehatan sebesar 93\%, rata-rata jumlah pengaruh budaya dari faktor kebijakan dan peraturan yang berlaku sebesar 90\% sedangkan yang cukup sebesar $8 \%$ dan yang rendah $2 \%$. Faktor kebijakan dan peraturan yang berlaku dalam budaya masyarakat terhadap karakteristik masyarakat tinggi signifikan karena sebesar $90 \%$. Sesuai dengan Surat Edaran Gubernur Jawa Timur No. 460/11166/031/2014 tentang Pembebasan Korban Penderita Skizofrenia yang dipasung.

Dalam bidang pelayanan saat ini jumlah fasilitas pelayanan kesehatan yang melaksanakan pelayanan kesehatan jiwa makin bertambah. 
Diharapkan hal ini akan memudahkan ODGJ mendapat pengobatan sehingga mengurangi pemasungan.

Sejalan dengan surat edaran Gubernur Jawa Timur, di kota Blitar dibentuk Tim Pelaksana Kesehatan Jiwa Masyarakat (TPKJM) kota Blitar. Ada 16 anggota yang terlibat dalam kepengurusan, baik SKPD pemerintah maupun non-pemerintah. Salah satu diantaranya Bapemas, Bappeda, Dinas Sosial dan Tenaga Kerja, para camat dan lurah se Kota Blitar, kepolisian, TNI, prodi keperawatan, koordinator LSM se kota Blitar dan lainnya. Kebijakan dan peraturan yang berlaku yang didukung oleh surat keputusan / surat edaran dari Provinsi tingkat I sampai dengan pembentukan tim TPKJM tingkat kota Blitar mendorong masyarakat untuk mengembangkan diri untuk menambah pengetahuan dan mengubah perilakunya didalam pembebasan pasung dan melakukan koordinasi bersama-sama baik mulai keluarga, tokoh masyarakat dan tokoh agama, kader kesehatan jiwa dan tenaga kesehatan untuk melakukan pembebasan pemasungan dan mengikuti peraturan kebijakan untuk perawatan dan pengobatan di Puskesmas maupun di Rumah Sakit Jiwa setelah dibebaskan dari pemasungan.

Faktor ekonomi terhadap karakteristik masyarakat sesuai fakta diatas, bahwa faktor ekonomi yang tinggi dari unsur Keluarga sebesar $58 \%$, pada TOGA/TOMA sebesar $68 \%$, pada Kader Kesehatan sebesar 73\%, pada Tenaga Kesehatan sebesar $66 \%$, rata-rata jumlah pengaruh budaya dari faktor ekonomi sebesar $67 \%$ sedangkan yang cukup sebesar $15 \%$ dan yang rendah 19\%. Faktor ekonomi dalam budaya masyarakat terhadap karakteristik masyarakat yang signifikan sebesar $67 \%$.

Menurut Polanyi et al., (1957) ekonomi dalam masyarakat pra industri melekat dalam institusi-institusi sosial, politik dan agama. Ini berarti bahwa fenomena seperti perdagangan, uang dan pasar diilhami tujuan selain dari mencari keuntungan. Kehidupan ekonomi dalam masyarakat pra industri diatur oleh resiprositas dan redistribusi.

Mekanisme pasar tidak dibolehkan untuk mendominasi kehidupan ekonomi, oleh karena itu permiantaan dan penawaran bukan sebagai pembentuk harga tetapi lebih kepada tradisi atau otoritas politik. Sebaliknya dalam masyarakat modern, "pasar yang menetapkan harga" diatur oleh suatu logika baru, yaitu logika yang menyatakan bahwa tindakan ekonomi tidak mesti melekat dalam masyarakat.

Berdasarkan fakta dan teori diatas menunjukkan bahwa pekerjaan klien dan tingkat sosial ekonomi dari keluarga, tabungan yang dimiliki oleh keluarga ikut membantu menentukan pemberdayaan masyarakat didalam pembiayaan pengobatan bagi ODGJ dan perawatan serta pengobatan baik pada saat pembebasan pasung maupun saat pengobatan di Rumah Sakit Jiwa dan pasca pengobatan (sepulang dari Rumah Sakit) dan sejumlah 33\% masyarakat sosial ekonominya rendah dengan adanya program pemerintah melalui asuransi kesehatan / BPJS dan pengobatan gratis sangat membantu masyarakat didalam melakukan perawatan dan pengobatan penderita gangguan jiwa (ODGJ) sehingga tidak mengkhawatirkan dalam segi ekonomi untuk melakukan langkah-langkah pembebasan pasung.

Faktor pendidikan terhadap karakteristik masyarakat sesuai fakta diatas, bahwa faktor pendidikan yang tinggi dari unsur Keluarga sebesar 62\%, pada TOGA/TOMA sebesar $76 \%$, pada Kader Kesehatan sebesar 71\%, pada Tenaga Kesehatan sebesar 70\%, rata-rata jumlah pengaruh budaya dari faktor pendidikan sebesar $69 \%$ sedangkan yang cukup sebesar $17 \%$ dan yang rendah $13 \%$.

Faktor pendidikan dalam budaya masyarakat terhadap karakteristik masyarakat yang signifikan sebesar $69 \%$. Pendidikan secara praktis tak dapat dipisahkan dengan nilai-nilai 
budaya. Dalam menjaga dan melestarikan kebudayaan sendiri, secara proses mentransfernya yang paling efektif dengan cara pendidikan. Keduanya sangat erat sekali hubungannya karena saling melengkapi dan mendukung antara satu sama lainnya. Tujuan pendidikan pun adalah melestarikan dan selalu meningkatkan kebudayaan itu sendiri, dengan adanya pendidikanlah kita bisa mentransfer kebudayaan itu sendiri dari generasi ke generasi selanjutnya (Carter, 1973).

Menurut Dewey (2007), pendidikan merupakan suatu proses pengalaman. Karena kehidupan merupakan pertumbuhan, maka pendidikan berarti membantu pertumbuhan batin manusia tanpa dibatasi oleh usia. Proses pertumbuhan adalah proses penyesuaian pada setiap fase dan menambah kecakapan dalam perkembangan seseorang melalui pendidikan. Menurut Ki Hajar Dewantara, pendidikan adalah suatu tuntutan di dalam hidup tumbuhnya anakanak. Maksudnya ialah bahwa pendidikan menuntun segala kekuatan kodrat yang ada pada peserta didik agar sebagai manusia dan anggota masyarakat dapat mencapai keselamatan dan kebahagiaan hidup yang setinggi-tingginya.

Berdasarkan fakta dan teori diatas tingkat pendidikan masyarakat yang tinggi sebesar $69 \%$ artinya bahwa pendidikan berpengaruh pada pemberdayaan masyarakat dalam membebaskan penderita dari pemasungan baik pada tingkat persiapan maupun pelaksanaan sampai dengan paska pengobatan dari Rumah Sakit Jiwa.

Hal ini sesuai dengan teorinya Leininger (2002) menyatakan bahwa suatu area/wilayah keilmuwan budaya pada proses belajar dan praktek keperawatan yang fokus memandang perbedaan dan kesamaan diantara budaya dengan menghargai asuhan, sehat dan sakit didasarkan pada nilai budaya manusia, kepercayaan dan tindakan, dan ilmu ini digunakan untuk memberikan asuhan keperawatan khususnya budaya atau keutuhan budaya kepada manusia (Leininger, 2002).

Berdasarkan fakta dan teori diatas, budaya masyarakat khususnya budaya Jawa sangat berpengaruh pada model pemberdayaan dalam pembebasan pasung. Walaupun tidak semua unsur budaya berpengaruh pada pemberdayaan namun sebagian besar berpengaruh pada masyarakat.

Analisis permasalahan pemberdayaan masyarakat dalam pembebasan pasung. Berdasarkan hasil Nominal Group Technique yang dilakukan pada tanggal 8 Oktober 2016 hari Sabtu dari kelompok Masyarakat baik dari Keluarga ODGJ yang dipasung, TOGA/TOMA, Kader Kesehatan Jiwa dan Tenaga Kesehatan didapatkan permasalahan dalam pembebasan pasung seperti yang diungkap oleh masing-masing kelompok sebagai berikut :

\section{Kelompok keluarga ODGJ yang dipasung}

Permasalahan yang dirasakan saat ini jika penderita dilepaskan dari pemasungan terdapat kekhawatiran seperti mengancam, mutilasi sambil memegang barang agar bisa memukul, mengamuk dan menyalahkan orang lain jika dilepas dari pemasungan, ingin dilepas asalkan ada barang yang diminta, akan membuang barang jika diberi emas, ketika makan biasanya akan melempar piring dan gelas ke dinding ataupun ke orang lain, dipasung menggunakan rantai, biasanya mengamuk dengan cara memukul atau menariknarik rambut, tidak mau meminum obat karena rahang mulut terasa kaku dan obat langsung dibuang, keluarga khawatir jika dilepas akan mengganggu orang lain seperti kencing dimanamana, merusak lingkungan dengan cara mencabut tanaman tetangga ataupun memasukkan barangbarang kedalam sumur tetangga, tekanan dari keinginan anak dan keinginan orang tua yang berbeda akhirnya terjadi gangguan jiwa dan dilakukan pemasungan.

Hal yang perlu dilakukan jika ODGJ dilepas dari pemasungan adalah melakukan pengobatan 
yang teratur dan rujukan jika memungkinkan, serta dibawa ke RS Jiwa hingga sembuh agar mau minum obat lagi, karena jika di rumah tidak mau minum obat dan alangkah lebih baik jika Puskesmas yang merujuk ke RS Jiwa.

Pengobatan yang dilakukan harus rutin dan dikasih kesibukan atau pekerjaan agar tidak teringat dengan masa lalu, jangan diasingkan atau dikucilkan dari lingkungan masyarakat, selalu ada pendampingan dari keluarga agar pasien tidak merasa sendiri.

\section{Kelompok TOGA / TOMA}

Permasalahan yang dirasakan saat ini oleh TOGA/TOMA seperti pengalaman terbatas, sehingga pengalaman keluarga beranggapan lebih baik dipasung dan pengobatan yang paling efektif hanya pemasungan, ekonomi lemah, sehingga keluarga beranggapan bahwa biaya untuk pengobatan dan perawatan penderita itu mahal, tidak ada dukungan dari saudara, sehingga keluarga berusaha sendiri sesuai kemampuan dan ternyata mereka tidak mampu (kepedulian saudara kurang). Sebagai tokoh masyarakat memberikan informasi kepada keluarga bahwa ODGJ masih bisa ditangani tanpa harus dipasung. Jika masih tetap dipasung, maka tokoh masyarakat akan berkoordinasi dengan Dinas kesehatan, dan Puskesmas untuk menindaklanjuti pengobatan dan perawatan secara medis.

Menyampaikan kepada keluarga penderita bahwa semua umat manusia mempunyai hak untuk hidup yang layak sesuai dengan UUD 1945. Kejadian seperti ini menjadi tanggung jawab bersama, antara lain masyarakat ikut berperan dan yang lebih penting pemerintah. Sehingga muncul pengelola medis seperti UPTD kesehatan, Rumah Sakit lebih aktif dan peduli kepada masyarakat yang terkena gangguan jiwa untuk mendapat perhatian khusus sehingga segera menadapat penanganan lebih lanjut dan diselesaikan masalah terkait keluarga. Memberikan pemahaman keluarga penderita terkait penanganan supaya tidak dilakukan pemasungan, karena masih ada penanganan medis yang paling efektif untuk bisa menangani masalah tersebut. Memberikan informasi terkait UUD, tentang hukum pidana.

Bersama-sama mempengaruhi pendapat keluarga dengan memberi masukan, dan memberi dorongan motivasi. Berkomitmen bersama bahwa sebagai tokoh masyarakat untuk mengupayakan pembebasan pasung terkait perwakilan keluarga, tokoh masyarakat, tokoh agama dan petugas kesehatan untuk dilakukan tindakan bebas pasung, dan koordinasi untuk musyawarah.

\section{Kelompok Kader Kesehatan Jiwa}

Permasalahan yang dirasakan saat ini oleh Kader Kesehatan Jiwa seperti masalah pada penderita ODGJ, karena perilaku yang merusak dan mengganggu lingkungan masyarakat, kurangnya dukungan dari keluarga itu sendiri karena pendukung utama dari keluarga, takut kehilangan anggota keluarga/ODGJ. Oleh sebab itu, hal yang perlu dilakukan adalah melakukan pendampingan untuk pergi berobat ke puskesmas (kartu dibawa oleh kader), melakukan pendampingan minum obat secara teratur, memberi tanggung jawab kepada penderita, dukungan dan motivasi kader kesehatan, melakukan pendekatan pada keluarga maupun ODGJ, melakukan pengawasan minum obat serta memotivasi dan memberikan pengertian kepada Keluarga maupun pada ODGJ.

Definisi pasung dalam masyarakat adalah hal yang menakutkan sehingga masyarakat takut untuk membantu melakukan pembebasan pasung, oleh sebab itu paradigma / definisi pasung harus dirubah agar masyarakat mau membantu untuk pembebasan pasung. Dinas terkait juga harus aktif memberikan sosialisasi kepada masyarakat untuk melaporkan dan berobat secara teratur. Kader harus diberi bekal untuk menangani dari dinas terkait serta Kader 
harus bisa dan tahu jika ada pasien kambuh, ditambah dengan adanya jadwal kunjungan ke keluarga dan ODGJ yang dipasung.

\section{Kelompok Tenaga Kesehatan}

Permasalahan yang dirasakan saat ini oleh Tenaga Kesehatan seperti Penderita masih dialihkan sebagai aib, persepsi keluarga yang salah pada penderita ODGJ tentang penyakitnya, kurang pengetahuan dan minimnya akses ke Tenaga Kesehatan untuk penderita ODGJ, ketidakmauan keluarga untuk direpotkan, kejenuhan keluarga untuk perawatan dan pengobatan ODGJ, minimnya faktor ekonomi pada keluarga ODGJ dan belum memiliki jaminan kesehatan. Adanya tekanan dari masyarakat sekitar karena merasa terganggu, kurangnya dukungan dari lingkungan dan tidak ada jaminan keamanan dari masyarakat.

Oleh sebab itu perlu dilakukan edukasi terhadap keluarga dan masyarakat, menyiapkan rujukan, koordinasi lintas sektor, Menyiapkan dokumen yang diperlukan untuk keperluan pembiayaan pasien, komitmen keluarga untuk pelaksanaan pengobatan dan perawatan. Alangkah baiknya jika Pemerintah memberikan bantuan pembiayaan ODGJ bagi yang tidak mampu seumur hidup, adanya pembekalan skilll/ ketrampilan pada pasien ODGJ untuk meningkatkan kualitas hidup ODGJ, memberikan prioritas pelayanan kesehatan bagi pasien ODGJ.

Memberikan edukasi dan wawasan tentang ODGJ kepada keluarga, edukasi kepada pasien dan keluarga untuk keteraturan minum obat dan berobat, memberikan aktivitas pada ODGJ yang bermanfaat, memperlakukan ODGJ secara manusiawi dan tidak mendiskriminasi serta memaksimalkan peran paguyuban kesehatan jiwa, tokoh agama dan tokoh masyarakat. Selain itu, penambahan jumlah tenaga kesehatan ahli jiwa (dokter spesialis, perawat spesialis jiwa) juga diperlukan di fasilitas kesehatan primer bukan di fasilitas rujukan sekaligus penambahan tenaga psikolog.

Menurut Berdasarkan UU No. 36 Tahun 2014, Tenaga Kesehatan adalah setiap orang yang mengabdikan diri dalam bidang kesehatan serta memiliki pengetahuan dan/atau keterampilan melalui pendidikan di bidang kesehatan yang untuk jenis tertentu memerlukan kewenangan untuk melakukan upaya kesehatan.

Berdasarkan fakta dan teori diatas tenaga kesehatan merupakan kelompok strategis dalam program pemberdayaan masyarakat untuk pembebasan pasung baik dalam melakukan deteksi dini kasus pemasungan gerakan masyarakat untuk pembebasan pasung, mengorganisir masyarakat untuk pembebasan pasung dan perawatan penderita paska pemasungan di kota Blitar.

Berdasarkan gambar model pembebasan pasung, maka pengembangan kemampuan masyarakat untuk pembebasan pasung yang paling efektif adalah Kader Kesehatan sebesar 94\%, TOGA/TOMA sebesar 91\%, Tenaga Kesehatan sebesar 90\% dan Keluarga sebesar 85\%. Sedangkan pemberdayaan masyarakat untuk melakukan pembebasan pasung yang paling efektif adalah Tenaga Kesehatan sebesar 91\%, Keluarga sebesar $85 \%$, dan TOGA/TOMA sebesar $80 \%$.

Sedangkan kemampuan masyarakat untuk mengorganisir masyarakat didalam pembebasan pasung yang paling efektif adalah Kader Kesehatan sebesar 100\%, TOGA/TOMA sebesar $95 \%$, Keluarga sebesar 90\%, dan Tenaga Kesehatan sebesar $88 \%$.

Berdasarkan evaluasi saat uji coba model pemberdayaan masyarakat untuk pembebasan pasung pada tanggal 4 Nopember 2016 di 3 UPTD Kota Blitar yaitu Puskesmas Sukorejo, Puskesmas Kepanjenkidul dan Puskesmas Sananwetan. Hasil evaluasi pengembangan kemampuan masyarakat untuk melepaskan pasung adalah Kader Kesehatan dan Petugas Kesehatan diperoleh dengan hasil tinggi, untuk 
TOGA/TOMA diperoleh hasil sedang dan Keluarga diperoleh hasil cukup.

Hasil evaluasi melakukan pembebasan penderita yang dipasung adalah Keluarga dan Petugas Kesehatan diperoleh hasil tinggi, untuk TOGA/TOMA dan Kader Kesehatan diperoleh hasil sedang. Hasil evaluasi menggerakkan masyarakat untuk membebaskan penderita dari pemasungan adalah TOGA / TOMA dan Kader Kesehatan diperoleh hasil tinggi, untuk Petugas Kesehatan diperoleh hasil sedang dan Keluarga diperoleh hasil cukup.

Hasil penelitian pada potensi masyarakat dalam pemberdayaaan pembebasan pasung : pengaruh budaya terhadap tindakan masyarakat melakukan pelepasan pasung. Masyarakat yang paling berpotensi untuk pengembangan pengetahuan dalam pembebasan pasung adalah kelompok Kader Kesehatan (94\%). Penelitian ini sejalan dengan pendapat yang dikemukakan Bartle (2003) yang menyatakan bahwa tujuan pemberdayaan masyarakat dibidang kesehatan adalah tumbuhnya kesadaran, kemauan pemahaman akan kesehatan, bagi individu, kelompok atau masyarakat. Kesediaan masyarakat menjadi kader kesehatan secara penuh dalam pembebasan pasung sesuai dengan prinsip pemberdayaan masyarakat (community empowerment). Sedangkan untuk masyarakat yang mengubah perilaku pembebasan pasung adalah Tenaga Kesehatan (91\%). Sedangkan yang paling berpotensi untuk menggerakkan / mengorganisir diri dan lingkungan untuk membebaskan pemasungan adalah Kader Kesehatan Jiwa (100\%).

Pengaruh budaya terhadap tindakan pemberdayaan masyarakat pada kemampuan untuk pengembangan pengetahuan pembebasan pasung adalah faktor agama dan filsafat hidup, nilai budaya dan gaya hidup, faktor kebijakan dan peraturan yang berlaku hal ini sejalan dengan teorinya Koentjaraningrat (2009) dan Paul
(2007) yang menyatakan bahwa sikap atau kesediaan untuk bertindak dan bukan merupakan pelaksaan motif tertentu, akan tetapi merupakan sesuatu predesposisi tindakan atau perilaku. Kesediaan Kader Kesehatan masyarakat untuk melakukan tindakan dalam pembebasan pasung.

Pengaruh budaya terhadap tindakan masyarakat untuk melakukan tindakan pelepasan pasung ternyata faktor agama dan filsafat hidup $(0,021)$ faktor pendidikan $(0,024)$. Hal ini sejalan dengan terorinya Notoatmodjo (2003) bahwa tingkat pendidikan seseorang mempengaruhi keputusan untuk mengambil langkah atau tindakan termasuk didalam melakukan tindakan yang belum pernah dilakukan. Namun seseorang yang tingkat pengetahuannya rendah tetapi banyak mendapatkan informasi yang baik dari berbagai media, hal ini juga bisa meningkatkan pengetahuan seseorang. Faktanya umur dan pendidikan masyarakat mampu melakukan langkah-langkah pembebasan pasung dan mampu menggerakkan masyarakat untuk membebaskan pasung.

Pengaruh budaya terhadap tindakan masyarakat untuk melakukan gerakan yang melibatkan orang banyak untuk melakukan pembebasan pasung, hal ini sejalan dengan teorinya faktor teknologi budaya, nilai budaya dan gaya hidup, faktor kebijakan dan peraturan yang berlaku dimungkinkan berpengaruh pada penggerakan masyarakat untuk membebaskan pasung.

Masyarakat yang dapat diberdayakan untuk melakukan pembebasan pasung meliputi Keluarga pasien, Tokoh Agama/tokoh masyarakat, Kader kesehatan jiwa, Petugas kesehatan. Keluarga pasien, dengan upaya pembebasan pasung keluarga sangat mendukung upaya pembebasan pasung terbukti dari hasil pengolahan data dalam keinginan membebaskan pemasungan untuk berperilaku melepaskan dari pemasungan, untuk melibatkan masyarakat sekitarnya untuk membebaskan pasung. 
Berdasarkan ungkapan keluarga penderita yang dipasung keluarga masih mengkhawatirkan jika penderita benar-benar dibebaskan dari pemasungan ialah khawatir jika penderita pergi keluyuran tanpa arah, sehingga dapat merepotkan anggota keluarga yang lain. Dalam hal ini perlu sistem pelaporan keluarga pasien ke RT/RW, Desa, Kepolisian, Babinsa, Pamong Praja, atau Satpol PP. Ancaman melakukan kekerasan terhadap lingkungan jika keinginannya tidak terpenuhi sehingga membuat keributan lingkungan rumah dan tetangga, disamping pengekangan/ himbauan keluarga membuat suasana permusuhan dengan pasien yang berdampak pada penganiayaan pasien pada keluarga. Sehingga diperlukan langkah-langkah antisipasi keluarga agar hubungan sosial tetap terjaga dan tidak memancing suasana emosional pasien.

Tindakan peningkatan/ pemasungan sendiri sebenarnya disadari oleh keluarga seperti yang diungkapkan oleh keluarga $X$ yang menyatakan: "saya takut kalau ikut mengikat atau memasung pasien, karena pasien akan mengingat dan selanjutnya pasien akan melakukan ancaman kepada saya”.

\section{PENUTUP}

Faktor agama dan filsafat hidup, faktor sosial dan keterikatan keluarga, faktor nilai budaya dan gaya hidup, faktor kebijakan dan peraturan yang ada mempengaruhi pengembangan kemampuan masyarakat untuk melepaskan penderita pasung. Sedangkan faktor masyarakat, faktor teknologi, faktor sosial dan keterikatan keluarga, faktor nilai budaya dan gaya hidup, dan faktor kebijakan dan peraturan berpengaruh pada pengubahan perilaku masyarakat untuk membebaskan penderita dari pemasungan.

Masyarakat yang paling berpotensi dalam pengembangan untuk peningkatan kemampuan adalah kelompok Kader Kesehatan Jiwa (94\%), sedangkan untuk masyarakat yang potensi mengubah perilaku untuk melakukan pembebasan pasung adalah kelompok Tenaga Kesehatan (91\%), masyarakat yang paling berpotensi untuk menggerakkan/ mengorganisasi diri dan lingkungan untuk pembebasan pemasungan adalah kelompok Kader Kesehatan $(100 \%)$.

Pengembangan model pembebasan pasung yang paling tepat adalah menggerakkan kegiatan melalui Kader Kesehatan dan Tenaga Kesehatan. Model pemberdayaan masyarakat untuk membebaskan pasung yang paling efektif adalah selalu melibatkan Kader kesehatan dan Tenaga Kesehatan.

Perlunya tim khusus yang menangani pembebasan pasung dengan melibatkan partisipasi masyarakat dengan mengedepankan Kader Kesehatan Jiwa dan Petugas Kesehatan yang ada di daerah tersebut. Perlu langkahlangkah penjadwalan kegiatan pembebasan pasung dengan melibatkan Dinas Kesehatan sebagai Leading Sector dan Dinas Sosial untuk memberikan dukungan sosial dalam pembebasan pasung.

Penelitian lanjutan dapat dilakukan dengan mengungkap tentang permasalahan disekitar proses pelepasan pasung dan pasca pelepasan pasung.

\section{DAFTAR PUSTAKA}

Bartle, P. (2003). Key Words C of Community Development, Empowerment, Participation: http://www.scn.org/ip/cds/cmp/ key-c.htm).

BPS Jatim. (2013). Jawa Timur dalam Angka. www.jatimprov.go.id.

Carter V. Good. (1973). Dictionary of Education. New York: Mc.Graw Hill.

Depkes. (2008). Riset Kesehatan Dasar tahun 2007. Jakarta: Depkes RI

Dewey, J. (2007). Experience and education. 
Simon and Schuster.

Dirjen Binkesmas Depkes RI. (2003). Buku Pedoman umum: TPKJM tim Pembina, pengarah dan pelaksana kesehatan jiwa masyarakat.Jakarta: DepkesRI

Donell, M.G \& Shorrt, R.A. (2003). Burden in schizophrenia caregiver: impact of Family Psycoeducation and Awareness of Patient Suicidality. Family Process, Vol. 42, no 1, pg 91-103

Ekman, Paul. (2007). Membaca Emosi Orang. Yogyakarta: Think

Friedman. (1998). Keperawatan Keluarga Teori dan Praktek . Edisi 3. EGC. Jakarta

Frisch, N. C. \& Frisch, L.E. (2006). Psychiatric Mental health Nursing. (3 th ed.). Clifton ParkNY : Thomson

Goffman, Erving. (1959). The Presentation of Self in Everyday Life. Reat Britain: Penguin Book, Cox \& Wyman Ltd.

Hills, M. D. (2002). Kluckhohn and Strodtbeck's values orientation theory. Online readings in psychology and culture, 4(4), 3.

Kementerian Kesehatan RI. (2013). Riset Kesehatan Dasar Tahun 2013. Jakarta

Koentjaranigrat. 1994. Kebudayaan Mentalitas dan Pembangunan. Jakarta : Gramedia Pustaka Utama

Leininger, M. M., \& McFarland, M. R. (2002). Transcultural nursing concepts, theories, research and practice.

Magliano,L. (2008). Families of People with severe mental disorders: difficulties and resources. http//www.euro.who.int/document/MNH/family-burden.

Maramis, WF.(2004). Ilmu Kedokteran Jiwa. Surabaya: Airlangga University Press

Maslim, R. (2001). Buku saku: Diagnosis gangguan jiwa. Jakarta: PT Nuh Jaya

Mohr, W. K. (2006). Psychiatric mental health nursing. (6 th ed.). Philadelphia: Lipincott
Williams Wilkins.

Moloeng, L.J. (2004). Metodologi penelitian kualitatif. Bandung: PT. Remaja Putra Karya.

Murthy, S.. (2003).Family interventions and empowerment as an approach to enhance mental health resources in developing countries.www.pubmedcentral.nih.gov.

Niels Mulder. (1980). Kebatinan dan Hidup Sehari-hari Orang Jawa; Kelangsungan dan Perubahan Kulturil. Jakarta: Gramedia.

Notoatmojo,S.(2003).Pendidikan dan perilaku kesehatan.Jakarta: Rineka Cipta

Nursalam (2013), Metodologi Penelitian Ilmu Keperawatan Pendekatan Praktis. Jakarta: Salemba Medika

Polanyi, K. (1957). The great transformation: (The political and economic origin of our time). Beacon Press.

Polit, D. F., \& Beck,C.T. (2004). Nursing Research: Priciples and Methods. 7 th edition. Philadelphia: Lippincott Williams \& Wilkins

Speziale , H.J.S, \& Carpenter, D.R. (2003). Qualitatif Research In Nursing (3th ed.). Philadelphia: Lippincott Williams \& Wilkins.

Stuart, G.W., \& Laraia M.T. (2005). Principles and practice of psychiatric nursing, $\left(8^{\text {th }}\right.$ ed), St. Louis: Mosby.

Suwarno Imam S. (2005). Konsep Tuhan, Manusia, Mistik Dalam Berbagai Kebatinan Jawa. Jakarta: Rajawali Pers

Varcarolis E. M, Carson, V.B., \& Shoemaker, N.C. (2006). Foundations of psychiatric mental health nursing $5^{\text {th }} e d$. St. Louis Missouri: Saunders Elsevier

Wartaya W.Y. (1987). Ilmu dan Teknologi sebagai Kerangka Budaya Modern. Majalah Basis

WHO. (2001). The world Health Report: 2001: mental health: new Understand- 
ing, newhope. www.who.int/whr/2001/en/

Word Federation For Mental health (2008).

Leraning about Schizophrenia: An international Mental Health Awareness

Packet. Http:///www.wfmh.org. 